Kasiram M, Partab R, Lawrence $S$ \& Dustin D

\title{
EXPLORING ARTICULATION AND PARTNERING OF SOCIAL WORK PROGRAMMES AT THE UNIVERSITY OF DURBAN -WESTVILLE (UDW) AND NORTH LONDON (UNL)
}

Prof $M$ Kasiram is an Associate Professor and Ms $R$ Partab a Lecturer at the University of Durban-Westville, School of Social Work. Drs S Lawrence and D Dustin are Lecturers at the University of North London, School of Applied Social Studies.

\section{INTRODUCTION}

As a result of an exploratory visit by Kasiram and Partab to the University of North London to investigate partnering possibilities between the two Universities, it was agreed that a comparative study of the Social Work programmes at both Universities be undertaken. The University of North London had already devised a post hoc student survey as part of the General Social Care Council feedback for quality assurance. The survey was adapted and adopted for use by the University of Durban-Westville, Social Work. The results of the two surveys were compared.

\section{AIMS OF THE STUDY}

The overall aim of the study was curriculum development to ensure the "immortality" of social work (Ntusi, 1998:384). Monitoring, adjusting and ensuring relevance and the appropriateness of programmes/curricula cannot be over-emphasised (Burke, 1996:65; Taylor, 1999:175). A further objective was to investigate the possibility of partnering, collaborating and articulation of the programmes at both Universities, something which is becoming increasingly popular within a global, networked society (Kasiram, 2000:226).

\section{CONTEXT}

This study was conducted over a 2-year period between 2000 and 2001.

Student demographics at both Universities were examined to assess the extent to which comparisons of the sample were possible. Because social work is located within an ever-changing context (McKendrick, 1998:99), differences along with similarities need acknowledgement and understanding in view of the purposes of this study. Some similarities and differences are discussed below.

Both groups of students came from socially disadvantaged backgrounds. This is in accord with the mission statement of UDW, which prides itself in affording disadvantaged persons the opportunity of a higher education. UDW has made its mission to serve persons who were previously excluded from educational systems in the apartheid era (McKendrick, 1998:101). Ntusi (1998:380) describes social work as a profession which has historically served the disadvantaged, the disabled and those in despair. Thus the profession and UDW's mission statement have a common meeting point of serving the disenfranchised. Similarly, the mission statement of UNL is "The provision of education for personal development and social justice".

The distinct difference in the two groups was that students from UDW were predominantly younger, many entering social work directly after completion of their schooling. In comparison, students from UNL were older, having opted to enter social work after acquiring work experience. Another difference was in the qualifications of the two student groups, viz. a 2-year diploma in the case of the UNL sample and a 4-year degree in the case of the UDW sample. Although this 
difference may be perceived as a limitation in the study, it was clear that programme content and support were being evaluated with a view to exploring prospects for collaboration. Thus this difference did not detract from the main purposes of the study.

\section{RESEARCH METHODOLOGY}

The research team met on two occasions: first in July 2000 to discuss research methods and, secondly, in September 2001 to compare data. In addition, communication was maintained electronically.

The study was essentially exploratory, yielding qualitative and quantitative data. Comparative analyses were cautiously undertaken, heeding differences in sample characteristics.

The research instrument was a questionnaire that had to be mailed in the case of UNL respondents as they had already exited from the programme, whilst the UDW sample completed the questionnaire in the lecture room. Altogether 155 questionnaires were sent, with a return rate of 117 (93 students from UDW and 24 from UNL).

\section{RESULTS AND DISCUSSION}

\section{INVESTMENT IN STUDY}

The following table represents the responses of students regarding Social Work being worthwhile.

TABLE 1

INVESTMENT IN STUDY

\begin{tabular}{|l|c|c|}
\hline Responses & UDW & UNL \\
\hline Yes & 63 & 23 \\
\hline No & 17 & - \\
\hline No Response & 13 & 1 \\
\hline Total & 93 & 24 \\
\hline
\end{tabular}

From the above responses, it is clear that overall both sets of students considered their investment in the study of social work worthwhile.

The 17 respondents from UDW who responded negatively probably did so considering the status of social work in South Africa with respect to job scarcity, poor salaries and risks involved in practice (Naidoo, 2002). In contrast, in England social work jobs are plentiful and there is currently a drive to train and recruit social workers (Platt, 2000:25). Students who graduate from social work programmes in England would therefore expect to find employment.

Positive responses that were similar from UNL and UDW were:

- Being more confident, self-aware and reflective;

- Appreciation of the theory/methods in social work;

- Enhanced practice skills.

Specific positive UNL responses were as follows:

- Being equipped for specialist practice; 
- Acquiring knowledge of different systems, resources and how to service for special needs;

- Increased perception of client needs.

Specific positive UDW responses were:

- Learning about the work environment prior to graduating;

- Initiating community projects and exposure to social development;

- Teamwork exposure;

- Personal satisfaction and fulfilment;

- Exposure to multifaceted societal problems.

Learning about the work environment prior to graduating is considered necessary for the sake of professional and profession survival. Brown (1997:283) asserts that students should be prepared for all eventualities, even for corruption in the field. Positive responses from UDW students are likely to be related to their extensive practice education, which could serve to ensure some measure of survival of the profession in the face of harsh realities. Clearly, extensive practice education alone is insufficient to ensure survival, given the brain drain from the country (Naidoo, 2002).

Appreciation for learning about social and community development along with the multifaceted nature of societal problems reflects a "melding" of people-changing and society-changing goals (McKendrick, 1998:107). Given the extent of poverty in South Africa, is the theoretical and practical curriculum adequate?

Negative responses from the Universities were context specific, with one UNL student complaining of poor course administration and another that, financially, the investment was not worthwhile yet. A third student wished for more work to have been done on "questioning" themselves. UDW students complained of there being too much theory, some of which was considered irrelevant. Others wished for computer-facilitated learning and more practical work. These concerns are serious, especially if we are to address the call for relevance, survival and international marketability. The need was for more self-work at UNL and for some modules at UDW to be re-evaluated to keep abreast of the ever-changing milieu in South Africa.

Both sample groups indicated that the qualification had generally increased their job prospects (100\% UNL and 67\% UDW). As compared to the 100\% response rate amongst UNL respondents, UDW students were possibly apprehensive about securing employment in social work, as there are fewer social work positions in South Africa.

\section{PROGRAMME EVALUATION}

Three open-ended and one closed-ended question served to evaluate the Social Work programmes at the two Universities.

In the open-ended questions relating to aspects of the programme that were most helpful, both sample groups reported as follows:

- Practice education in different service organisations;

- Relevant theory such as mental health, family therapy, group work, community work, bereavement, assertiveness training, law, risk management and care planning, and awareness of AOP (anti-oppressive practice);

- Critical thinking and evidence-based practice. 
UNL students specifically mentioned the value of joint health and social science modules and the relevance of theory. Personal caring and social justice learning are discussed by Lynn (1999:940) as permeating practice, these being appreciated by the respondents in this study. Helpful modules are also commensurate with Lynn's observation (1999:948) that there must be a duality of approaches, viz. those that target all "divisions within a holistic, anti-oppressive and antidiscriminatory perspective". It should be noted here that anti-oppressive practice forms a significant component of the UK curriculum. South African tertiary institutions, too, could accommodate this component specifically, in accord with living in a new democracy. Evidencebased practice also needs attention, as South Africa evolves as a litigious nation.

When questioned on what they would appreciate changed, both student groups reported as follows:

- $\quad$ practice education;

- more time for community projects;

- less/more practice education;

- $\quad$ practice education to commence at level 1;

- less report writing, learning how to write reports;

- timeous placement;

- accessible placements;

- matching students with supervisor/placement.

These requests need to be addressed by staff at tertiary institutions involved in practice education. Community work projects should be carefully planned and timed to optimise learning. This request is commensurate with legislated concerns for more community work and development in South Africa (White Paper for Social Welfare, 1997).

Also, more attention needs to be afforded to the practice education programme to ensure accommodation of new emphases so that learning is developmental rather than simply incremental.

Also requested was the development of report writing skills and that there should be less recording. The question here is whether there is too much reliance on reports. Perhaps the profession and our training should consider more use of technology to replace or supplement reports. Students could be spending too much time on report writing instead of learning or acquiring much needed skills.

Specific UDW responses were:

- re-organisation of curriculum to allow for more Social Work modules; curriculum to suit South African context;

- $\quad$ student consultation in curriculum development;

- lecturing style to be more democratic;

- more computer support/facilities;

- research: to commence in the $3^{\text {rd }}$ year; preparation for research presentation,

- recognition of the $4^{\text {th }}$ year as Honours.

It must be noted that in some instances responses were seemingly contradictory, e.g. appreciating the theoretical content, yet wanting changes in the curriculum. This may be explained by the types 
of questions to which responses were made. When questions were general, responses were generally more positive than when specific questions were asked.

Curriculum change to address the South African context points to gaps between practice and education. The White Paper for Social Welfare has recognised that training does not equip graduates to respond to the social developmental needs of the country (Drower, 1999:237; Lombard, 1999:97). Besides heeding national pleas for a changed emphasis, universities should also heed requests for student consultation in curriculum development.

Other aspects mentioned by students in the open-ended question on programme evaluation are incorporated in the following table and explained below.

TABLE 2: PROGRAMME EVALUATION

\begin{tabular}{|l|c|c|c|c|c|c|c|c|c|c|}
\hline Programme components & $\begin{array}{c}\text { Good } \\
\text { UDW }\end{array}$ & $\begin{array}{c}\text { Good } \\
\text { UNL }\end{array}$ & $\begin{array}{c}\text { Ade- } \\
\text { quate } \\
\text { UDW }\end{array}$ & $\begin{array}{c}\text { Ade- } \\
\text { quate } \\
\text { UNL }\end{array}$ & $\begin{array}{c}\text { Poor } \\
\text { UDW }\end{array}$ & $\begin{array}{c}\text { Poor } \\
\text { UNL }\end{array}$ & $\begin{array}{c}\text { Unsatis } \\
\text { UDW }\end{array}$ & $\begin{array}{c}\text { Unsatis } \\
\text { UNL }\end{array}$ & $\begin{array}{c}\text { No } \\
\text { Resp } \\
\text { UDW }\end{array}$ & $\begin{array}{c}\text { No } \\
\text { Resp } \\
\text { UNL }\end{array}$ \\
\hline $\begin{array}{l}\text { Guidance and support } \\
\text { from staff }\end{array}$ & 59 & 4 & 21 & 12 & 6 & 8 & 2 & 1 & 5 & - \\
\hline $\begin{array}{l}\text { Practical work/Place- } \\
\text { ment opportunities }\end{array}$ & 59 & 6 & 22 & 5 & 3 & 6 & 2 & 7 & 7 & - \\
\hline $\begin{array}{l}\text { Facilities - library, } \\
\text { computers }\end{array}$ & 6 & 7 & 15 & 14 & 40 & 3 & 27 & - & 5 & - \\
\hline $\begin{array}{l}\text { Application of theory to } \\
\text { practice }\end{array}$ & 43 & 5 & 38 & 11 & 2 & 7 & 4 & 1 & 6 & - \\
\hline $\begin{array}{l}\text { Completion of disserta- } \\
\text { tion }\end{array}$ & 11 & - & 32 & - & 17 & - & 6 & - & 27 & - \\
\hline Seminar presentations & 43 & - & 29 & - & 8 & - & 4 & - & 7 & - \\
\hline Theory teaching & 59 & 6 & 24 & 14 & - & 3 & 3 & 1 & 7 & - \\
\hline Induction to programme & - & 6 & - & 10 & - & 6 & - & 2 & - & - \\
\hline Practice teaching & - & 12 & - & 8 & - & 3 & - & - & - & 1 \\
\hline
\end{tabular}

Guidance and support was generally perceived positively by the two sample groups. However, negative responses need serious consideration, since there is a need to guard against accommodating students for commercial and financial reasons with little evidence of a competent and committed faculty (Menachery \& Mohite, 2001:115).

Placement opportunities were viewed quite differently by the two sample groups. UDW students were satisfied with their practice placements in $87.1 \%$ of cases. Note should be taken here of the specific recommendations made by UDW students regarding placements and practice education. In comparison, only $46 \%$ of the UNL students reported being satisfied and $54 \%$ were dissatisfied with placement opportunities due to placement shortages at that time, a factor which has been addressed by reducing student intake and partnering with additional agencies. The opportunity for inter-university collaboration lies here in allowing for UK students to undertake some of their practice education requirements through universities in South Africa. This practice is indeed operational in other disciplines such as physiotherapy, so why not in Social Work? The profession in South Africa offers a variety of practice possibilities, this being the "marketable" commodity for attracting overseas students. 
UDW students were highly dissatisfied with infrastructural support compared to UNL students. Again, Menachery and Mohite (2001:115) noted that Social Work education was failing to have the desired impact because of substandard infrastructural support. There is no room for mediocrity in the face of competing for survival among tertiary education (Kasiram \& Partab, 2001). Rafferty (1997:961) too sees the need for IT support for managers, practitioners, consumers and trainers to enhance teaching and learning.

Application of theory to practice generally enjoyed positive responses by both student groups. Approximately one third (33.3\%) UNL students were concerned about the integration of theory and practice, although this statement contradicts responses made later in the questionnaire. In comparison only $7 \%$ of the UDW students expressed dissatisfaction with theory relating to practice, but a few students $(6.5 \%)$ did not respond to this question. The lack of consistency in students' responses with the open-ended question on what they would appreciate changed is noted. It would appear that UDW has made some attempt to heed the call for relevance and redressing of past imbalances. Taylor (1996:406) cautions against the preoccupation to professionalise social work at the expense of neglecting relevance. Weinstein (1996:35) too discusses the importance of relevance when she observed that there was clear preoccupation with teaching obsequious psychodynamic casework theories and neglecting what social workers actually do in practice. In a similar vein, Lynn (1999:950) and Menachery and Mohite (2001:116) refer to grounding programmes for job realities and imparting marketable and exclusive skills. Clearly UDW students perceived their curriculum as offering marketable skills to them as evidenced in the sizeable number of students who are recruited each year for practice abroad (Naidoo, 2002).

UDW students are required to complete a mini-dissertation in their final year of study. From the number that responded to this component (66), 43 (65\%) were satisfied and $23(35 \%)$ not. The number of dissatisfied students is a cause for concern and may be attributed to factors such as poor infrastructural support, de-motivated and academically weak students, the latter also appearing at some Asian Universities being prompted by the need to increase student intake into a programme (Menachery \& Mohite, 2001:114).

Seminar presentations, theory teaching, induction into the programme and practice teaching (supervision) were all favourably valued.

\section{SOCIAL WORK IN THE UK AND SA - DIFFERENCES AND SIMILARITIES}

An important difference between these two institutions is that they are working in different socioeconomic, political and cultural contexts. Internationally, social work is practised in many different contexts. What links social work in different social contexts is its role as mediator between the individual and the state or the wider society (Washington \& Paylor, 1998:336). There are essential similarities and differences in the role and knowledge base wherever social work is practised. Social workers adapt their role and knowledge base to the social context in which they practice. Social workers in South Africa work in a society that is very different from English society. The work environment promotes inclusion, community and nation building. Since 1994 the new democratic government in South Africa has had a comprehensive developmental strategy. The White Paper for Social Welfare (1997) has favoured the developmental approach, described as diverging from the residual, service-oriented approach to a holistically planned developmental approach that centralises human rights (Chetty, 1999). The theoretical paradigms that best support developmental activity and "nation building" are hermeneutic and critical theory. These perspectives favour the subjective nature of the client situation with individual and societal development as the targets for intervention (Erath \& Hamalainen, 2001). 
South African students in this survey mentioned that they would have liked theory to be more relevant to the South African context. This perception may stem from studying theories that are essential knowledge in Western social work that is oriented towards working with the individual, but may not be considered to be relevant in South Africa. There may be a perception that such theories are not relevant to the social and community development work that will contribute to nation building in South Africa. However, social work is always about balancing the needs of the individual and the community. Both need to be kept in the equation of social work practice. English social workers would perhaps like to return to more preventive community-based work, but are restricted from doing so in the current socio-economic and political climate. Social workers in South Africa are engaged in the excitement of nation building and developmental social work, but need to maintain attention to the individual as well.

\section{CONCLUSIONS AND RECOMMENDATIONS}

In evaluating Social Work programmes at both Universities, it was evident that students were generally satisfied, but the suggestions made for change need careful attention to promote relevance and enhance marketability. As regards partnering, it would seem that programmes at both Universities are quite dissimilar, being governed by the duration of the programme. However, both programmes offer students a generic training, albeit within different time frames. Therefore partnering prospects may be limited but not impossible, given shared characteristics such as student diversity and both Universities widening their access. In England plans are underway nationally to increase the length of qualifying professional social work training to three years from 2003 to bring UK in line with the agreed length of undergraduate training in Higher Education in the European Union under the Bologna Declaration (Lawrence \& Reverda, 2000).

Practice education emerged as an area worth exploring for exchange and partnering, and could take the form of blocks, rather than run concurrently with the theoretical teaching programme to accommodate articulation.

Student-student and educator-educator partnering is also a recommendation to create richness and diversity in learning. Modules that were favourably evaluated could be highlighted as those that could enjoy collaboration at the level of online exchange. The new telematic centre at UDW will allow for audio linkages and teleconferencing. Collaboration once established as a goal, though, needs nurturing as the "business of the day" can all too easily consume the life of the academic. The authors recommend that special time or staff need to be deployed for the purpose of promoting exchange and collaboration. However, the discipline first has to be convinced that this is a desirable goal. Only then can the momentum for a rich and relevant Social Work programme that merits international marketability be sustained.

\section{REFERENCES}

BROWN, M.J. 1997. Preparing social work students for a corrupt work environment. Maatskaplike Werk/Social Work, 35(3):282-284.

BURKE, P. 1996. Competences and the practicum: experiences on one social work course. Social Work Education, 15(3):60-75.

CHETTY, D. 1999. Social work in South Africa: historical antecedents and current challenges. European Journal of Social Work, 2(1):67-76.

DROWER, S. 1999. Directions from the East? Reflections on a visit to Asian Social Work Training Institutions. Maatskaplike Werk/Social Work, 35(3):282-284. 
ERATH, P. \& HAMALAINEN, J. 2001. Theory in social work. In: ADAMS, A.; ERATH, P. \& SHARDLOW, S. Key themes in European Social Work. Dorset: Russell House Publishing.

KASIRAM, M. 2000. Transforming "postgraduate offerings”. Maatskaplike Werk/Social Work, 36(3):261-267.

KASIRAM, M. \& PARTAB R. 2001. Partnering for success: marrying social work with religion and culture. Paper presentation at the $24^{\text {th }}$ International HERDSA conference, Newcastle, Australia, July 2001.

LAWRENCE, S. \& REVERDA, N. 2000. The recognition and accreditation of European postgraduate programmes. Social Work in Europe, 7(2):33-35.

LOMBARD, A. 1999. Transforming social work education in South Africa: a contextual and empowerment issue. Maatskaplike Werk/Social Work, 35(2):97-112.

LYNN, E. 1999. Value bases in social work education. British Journal of Social Work, 29(6):939-953.

MCKENDRICK, B. 1998. Social work education and training: from preparing for Apartheid society to training for a developing democracy. Maatskaplike Werk/Social Work, 34(1):99-111.

MENACHERY, J. \& MOHITE A. 2001. Whither social work education in Maharashtra. The Indian Journal of Social Work, 62(1):106-120.

MINISTRY OF EDUCATION 2001. National plan for higher education. Pretoria: Government Printer.

NAIDOO, S. 2002. The social work profession in South Africa. Quo Vadis? Durban: University of Durban-Westville. (Unpublished Doctoral Study)

NTUSI, T.M. 1998. Professional challenges for South African social workers: response to recent political changes. Maatskaplike Werk/Social Work, 34(4):380-388.

PLATT, D. 2000. Modern social services: a commitment to people. The $9^{\text {th }}$ Annual Report of the Chief Inspector of Social Services. London: Department of Health.

RAFFERTY, J. 1997. Critical comments. Shifting paradigms of information technology in social work education and practice. British Journal of Social Work, 27(7):959-974.

TAYLOR, I. 1996. Social work education. British Journal of Social Work, 26(3):406-412.

TAYLOR, I. 1999. Critical commentary. British Journal of Social Work, 29(1):175-180.

WASHINGTON, J. \& PAYLOR, I. 1998. Europe, social exclusion and the identity of social work. European Journal of Social Work, 1(3):327-338.

WEINSTEIN, J. 1996. Education and training for social work: a response to Tony Novak. Social Work in Education, 15(3):34-39.

WHITE PAPER FOR SOCIAL WELFARE. MINISTRY FOR WELFARE AND POPULATION DEVELOPMENT. 1997.

Government website: www.polity.org.za/govdocs/white-papers/welfare.html.

(Accessed 2002/03/12) 